\title{
PENGARUH KEPRIBADIAN DAN LINGKUNGAN KELUARGA TERHADAP MINAT BERWIRAUSAHA MAHASISWA MANAJEMEN FAKULTAS EKONOMI UNIVERSITAS TADULAKO
}

\author{
Muh. Yusuf \\ Syahir Natsir \\ Yoberth Kornelius \\ Jurusan Manajemen, Fakultas Ekonomi, Universitas Tadulako \\ Email: nugy.sbk.93@gmail.com
}

\begin{abstract}
The aim of this research is to determine simultaneous and partial influence of personality (X1) and family environment (X2) on entrepreneurial intentions (Y) of students. Subjects of this research involve students of The Management Department, Tadulako University with a sample of 88 respondents. This consists of 28 students of 2012 class, 26 students of 2013 class, and 34 students of 2014 class. Data collecting method apply observation, interviews, and questionnaires that analyzed with multiple linear regressions by using SPSS for Windows Release 16,0 software. The result shows that: 1) personality and family environment simultaneously have significant influence on entrepreneurial intention of student in the Management Department of University of Tadulako; 2) personality partially has significant influence on entrepreneurial intention of student in the Management Department of University of Tadulako; 3) family environment has significant influence on entrepreneurial intention of student in the Management Department of University of Tadulako.
\end{abstract}

Keywords: personality, family environment, entrepreneurial intention

\begin{abstract}
ABSTRAK
Penelitian ini bertujuan untuk mengetahui pengaruh secara serempak dan parsial dari kepribadian (X1) dan lingkungan keluarga (X2), terhadap Minat Berwirausaha (Y). Subjek dalam penelitian ini adalah mahasiswa Manajemen Fakultas Ekonomi Universitas Tadulako, dengan sampel 88 orang, yang terdiri dari 28 mahasiswa manajemen angkatan 2012, 26 mahasiswa manajemen angkatan 2013 dan 34 mahasiswa manajemen angkatan 2014. Pengambilan data menggunakan metode observasi, wawancara, dan kuesioner kemudian diolah dengan menggunakan alat analisis regresi linear berganda dengan program SPSS For Windows Release 16.0. Hasil penelitian ini menunjukkan bahwa 1) kepribadian dan lingkungan keluarga secara serempak berpengaruh signifikan terhadap Minat Berwirausaha mahasiswa Manajemen Fakultas Ekonomi Universitas Tadulako, 2) kepribadian berpengaruh signifikan terhadap Minat Berwirausaha mahasiswa Manajemen Fakultas Ekonomi Universitas Tadulako, dan 3) lingkungan keluarga berpengaruh signifikan terhadap Minat Berwirausaha mahasiswa Manajemen Fakultas Ekonomi Universitas Tadulako.
\end{abstract}

Kata Kunci: Kepribadian, Lingkungan Keluarga, Minat Berwirausaha

\section{Pendahuluan}

Perguruan tinggi merupakan lanjutan pendidikan menengah yang diselenggarakan untuk mempersiapkan peserta didik menjadi anggota masyarakat yang memiliki kemampuan akademis dan professional yang dapat menerapkan, mengembangkan, dan menciptakan ilmu pengetahuan, teknologi, dan kesenian. Setiap lulusan perguruan tinggi tentu mempunyai harapan dapat mengamalkan ilmu pengetahuan dan keterampilan yang telah didapat selama studi sebagai salah satu pilihan profesi.

Keberhasilan dari suatu aktivitas usaha pada dasarnya dipengaruhi oleh beberapa faktor. Alma (2011:52) menyebutkan bahwa terdapat beberapa sifat yang harus dimiliki oleh seorang wirausaha untuk menunjang karir sebagai wirausahawan tersebut, diantaranya : Percaya Diri, Berorientasi pada Tugas dan Hasil, Pengambilan Risiko, Kepemimpinan, Keorisinilan dan Berorientasi pada Masa Depan. 


\section{Yusuf M.}

Kepribadian adalah karakter yang dimiliki oleh seseorang. Dalam kepribadian seorang individu terdapat rasa percaya diri, berorientasi pada tugas dan hasil, berani mengambil risiko, berjiwa pemimpin, keorisinilan dan berorientasi ke depan. Tanpa adanya rasa percaya diri tentu tidak ada minat dari seorang individu untuk memutuskan berwirausaha. Selain itu keberanian dalam mengambil risiko juga merupakan tantangan besar bagi seorang wirausaha dalam menjalankan bisnisnya. Sifat kepemimpinan juga diperlukan dalam menjalankan sebuah usaha. Hal ini didasari dengan tujuan untuk tetap mengarahkan bawahan ataupun karyawan agar bekerja sesuai dengan tujuan yang hendak dicapai. Berdasarkan hasil observasi di lapangan mengenai kepribadian dengan wawancara mahasiswa manajemen Universitas Tadulako angkatan 2012 yang berinisial MH,

"seorang mahasiswa yang memiliki kepercayaan diri yang tinggi untuk berwirausaha maka akan selalu memiliki minat untuk berwirausaha, walaupun ada pengaruh atau bisikan dari luar bahwa berwirausaha menghadapi banyak risiko dan tantangan, seorang mahasiswa yang memiliki kepercayaan diri tidak akan terpengaruh karena memiliki keyakinan bahwa dia bisa menghadapi berbagai risiko dan tantangan"( MH. Mahasiswa jurusan manajemn 2012)

Lingkungan keluarga dianggap sebagai faktor yang dapat mempengaruhi keberhasilan usaha. Pada dasarnya keluarga merupakan tempat pendidikan pertama yang diterima oleh anak. Yusuf (2009:37) mengatakan bahwa perawatan orang tua yang penuh kasih sayang dan pendidikan tentang nilai-nilai kehidupan, baik agama maupun sosial budaya yang diberikannya merupakan faktor yang kondusif untuk mempersiapkan anak menjadi pribadi dan anggota masyarakat yang sehat. Alma (011:8) juga menjelaskan bahwa seringkali terlihat bahwa ada pengaruh dari orang tua yang bekerja sendiri, dan memiliki usaha sendiri cenderung anaknya akan menjadi pengusaha pula. Orang tua yang berlaku demikian cenderung mendukung serta mendorong keberanian anaknya untuk berdiri sendiri. Berdasarkan hasil observasi di lapangan mengenai lingkungan keluarga dengan wawancara mahasiswa yang berinisial $\mathrm{R}$,

"pada dasarnya untuk memulai suatu usaha atau berwirausaha tidak semudah dengan apa yang kita harapkan dukungan orang tua sangat penting, idealnya orang tua kita mengharapkan kita untuk mendapatkan pekerjaan yang lanyak, misalnya bekerja di kantoran atau perusahaan ". ( $R$ mahasiswa Jurusan Manajemen 2012)

Berdasarkan pemikiran tersebut, penulis meneliti bagaimana pengaruh kepribadian dan lingkungan keluarga terhadap minat berwirausaha. Oleh karena itu peneliti mangambil judul "Pengaruh Kepribadian dan Lingkungan Keluarga Terhadap Minat Berwirausaha Mahasiswa Program Studi Manajemen Fakultas Ekonomi Universitas Tadulako Angkatan 2012, 2013 dan 2014”.

Berdasarkan uraian di atas, maka tujuan dari penelitian ini adalah:

1. Untuk mengetahui dan menganalisis kepribadian dan lingkungan keluarga secara simultan berpengaruh signifikan terhadap minat berwirausaha mahasiswa Manajemen Fakultas Ekonomi Universitas Tadulako angkatan 2012, 2013 dan 2014.

2. Untuk mengetahui dan menganalisis kepribadian secara parsial berpengaruh signifikan terhadap minat berwirausaha mahasiswa Manajemen Fakultas Ekonomi Universitas Tadulako angkatan 2012, 2013 dan 2014.

3. Untuk mengetahui dan menganalisis lingkungan keluarga secara parsial berpengaruh signifikan terhadap minat berwirausaha mahasiswa Manajemen Fakultas Ekonomi Universitas Tadulako angkatan 2012, 2013 dan 2014. 


\section{KAJIAN LITERATUR DAN PENGEMBANGAN HIPOTESIS \\ Pengertian Kepribadian}

Menurut Allport (1961) faktor genetik dan lingkungan sama-sama berpegaruh dalam menentukan perilaku manusia, Hambali (2013:21-22). Bukan hanya faktor keturunan atau faktor lingkungan yang menentukan terbentuknya keperibadian, melainkan melalui pengaruh resiprokal faktor keturunan dan lingkungan yang memunculkan kerakteristik kepribadian.

\section{Faktor-faktor yang Mempengaruhi Keperibadian}

Perkembangan kepribadian individu dipengaruhi oleh berbagai faktor diantaranya faktor hereditas dan lingkungan Yusuf (2008:19). Faktor hereditas yang mempengaruhi kepribadian antara lain: bentuk tubuh, cairan tubuh, dan sifat-sifat yang diturunkan dari orang tua. Adapun faktor lingkungan antara lain lingkungan rumah, sekolah, dan masyarakat.

\section{Lingkungan Keluarga}

Keluarga adalah kelompok masyarakat terkecil yang terdiri dari ayah, ibu, anak, dan anggota keluarga yang lain. Keluarga merupakan peletak dasar bagi pertumbuhan dan perkembangan anak, disinilah yang memberikan pengaruh awal terhadap terbentuknya keperibadian.

Minat berwirausaha akan terbentuk apabila keluarga memberikan pengaruh positif terhadap minat tersebut, kerena sikap dan aktivitas sesama anggota keluarga saling mempengaruhi baik secara langsung maupun tidak langsung. Orang tua yang berwirausaha dalam bidang tertentu dapat menimbulkan minat anaknya untuk berwirausaha dalam sama yang sama pula, Paulina (2011:36).

\section{Indikator lingkungan keluarga dalam Minat Berwirausaha}

Terdapat tiga hal pokok yang mempengaruhi seseorang dalam hidupnya, Ketiga hal pokok tersebut berkaitan dengan keadaan individu terkait status dan perannya dalam keluarga ketiga hal pokok tersebut adalah sebagai berikut, Yusuf (2008:42): Keberfungsian Keluarga, Sikap dan Perlakuan Orang Tua terhadap Anak dan Status Ekonomi

\section{Pengertian Minat Berwirausaha \\ Kewirausahawan}

Totok S. Wiryasaputra $(2004 ; 16)$, wirausaha adalah orang yang ingin bebas, merdeka, mengatur kehidupannya sendiri, dan tidak bergantung pada belas kasihan orang lain. Mereka ingin menghasilkan uang sendiri. Uang didapatkan dari kekuatan dan usahanya sendiri. Mereka harus menciptakan sesuatu yang benar-benar baru atau memberi nilai tambah pada sesuatu yang mempunyai nilai untuk dijual atau layak dibeli sehingga menghasilkan uang bagi dirinya sendiri dan bahkan bagi orang yang di sekelilingnya.

\section{Tujuan dan Manfaat Kewirausahaan}

Cahyono (2013) mengemukakan tujuan dan manfaat kewirausahan :

1. Tujuan Kewirausahaan

a. Meningkatkan jumlah wirausaha yang sukses.

b. Menwujudkan kemampuan dan kemantapan para wirausahaan untuk menghasilkan kemampuan dan kesejahteraan masyarakat.

c. Membudayakan semangat, sikap, perilaku dan kemampuan kewirausahaan dikalangan masyarakat yang mampu, handal dan unggul.

d. Menumbuh kembangkan kesadaran kewirausahaan yang tangguh dan kuat.

2. Manfaat Kewirausahawan

a. Menambah daya tampung tenaga kerja sehingga dapat mengurangi pengangguran.

b. Memberi contoh bagaimana harus bekerja keras, tekun dan punya keperibadian unggul yang pantas diteladani. 


\section{Yusuf M.}

c. Berusaha mendidik para karyawan menjadi orang yang mandiri disiplin, tekun dan jujur dalam menghadapi pekerjaan.

d. Berusaha mendidik masyarakat agar hidup secara efesien, tidak berfoya-foya dan tidak boros.

e. Sebagai sumber penciptaan dan perluasan kesempatan kerja.

f. Pelaksana pembangunan bangsa dan negara.

g. Meningkatkan keperibadian dan mertabak/harga diri.

h. Memajukan keuangan.

i. Melaksanakan persaingan yang sehat dan wajar.

\section{Minat Berwirausaha}

Buchari Alma (2011: 5-6) faktor yang mendorong minat berwirausaha adalah lingkungan yang banyak di jumpai kegiatan-kegiatan berusaha, guru sekolah dan sekolah yang banyak mengajarkan kewirausahaan, teman pergaulan, lingkungan famili, sahabat yang dapat diajak berdiskusi tentang ide wirausaha, pendidikan formal, pengalaman bisnis kecil-kecilan.

\section{Hubungan Antar Variabel Penelitian}

\section{Hubungan Kepribadian dengan Minat Berwirausaha}

Keperibadian adalah suatu organisasi yang dinamis dari sistem psikofisik individu yang menuntukan tingkah laku dan pemikiran invidu secara khas, Allport (Adang Hambali, 2013:21-22) Sedangkan pengertian minat berwirausaha adalah berkemauan dan berkemampuan melihat kesempatan-kesempatan usaha untuk mengambil keuntungan darinya dengan mengambil tindakan yang tepat.

Penelitian yang dilakukan oleh Eka Aprilianty (2012) mengenai hubungan kepribadian dan kewirausahaan, ditemukan suatu hubungan positif antara kepribadiam dan kewirausahaan Kepribadian tersebut kadangkala membedakannya dari kebanyakan orang.

\section{Hubungan Lingkungan Keluarga Minat Berwirausaha}

Keluarga adalah kelompok masyarakat terkecil yang terdiri dari ayah, ibu, anak, dan anggota keluarga yang lain. Keluarga merupakan peletak dasar bagi pertumbuhan dan perkembangan anak, disinilah yang memberikan pengaruh awal terhadap terbentuknya keperibadian. Rasa tanggung jawab dan kreativitas dapat ditumbuhkan sedini mungkin sejak anak mulai berinteraksi dengan orang dewasa, Irene Paulina (2011:36).

\section{Kerangka Berfikir}

Berdasarkan latar belakang dan rumusan masalah yang telah diuraikan pada bab sebelumnya, maka dapat dijelaskan konseptual dari penelitian ini, variabel independen pada penelitian ini yaitu Kepribadian (X1) dan Lingkungan Keluarga (X2), sedangkan variabel dependen pada penelitian ini yaitu minat berwirausaha (Y). Yang dapat dilihat seperti gambar berikut: 


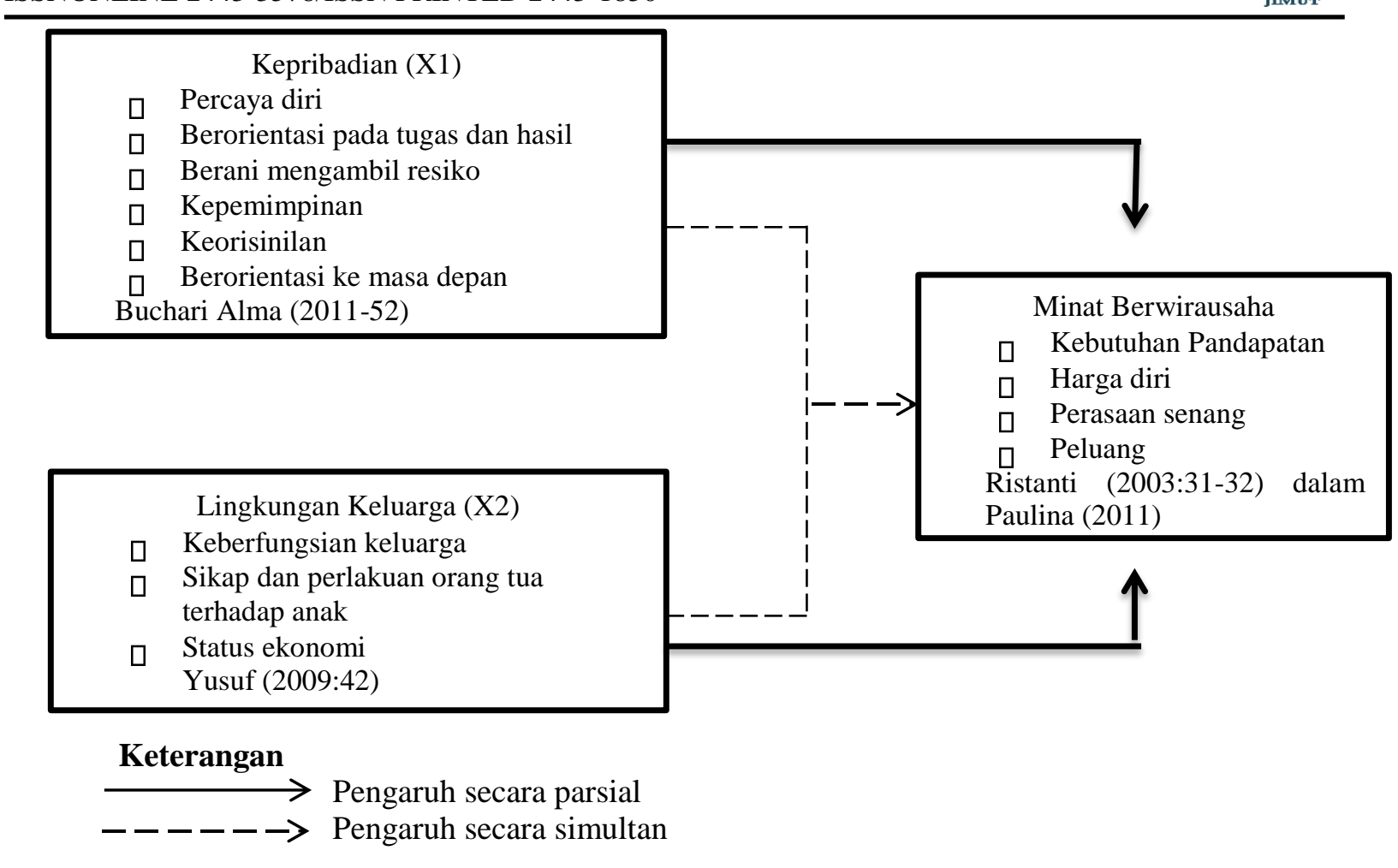

\section{Gambar 1 Kerangka Pemikiran}

Beranjak dari permasalahan-permasalahan pokok di atas, yang menjadi hipotesis penelitian ini adalah sebagai berikut :

1. Kepribadian dan Lingkungan Keluarga berpengaruh secara simultan terhadap minat berwirausaha terhadap mahasiswa jurusan manajemen Universitas Tadulako, angkatan 2012, 2013, dan 2014.

2. Kepribadian berpengaruh secara parsial terhadap minat berwirausaha terhadap mahasiswa jurusan manajemen Universitas Tadulako, angkatan 2012, 2013, dan 2014.

3. Lingkungan keluarga berpengaruh secara parsial terhadap minat berwirausaha terhadap mahasiswa jurusan manajemen Universitas Tadulako, angkatan 2012, 2013, dan 2014.

\section{METODE PENELITIAN}

Penelitian ini menggunakan tipe penelitian deskriptif-kausal. Kausalitas sebagai salah satu langkah untuk mengevaluasi hubungan antar variabel yang diteliti dalam bentuk pengujian hipotesis. Tadulako Fakultas Ekonomi jurusan Manajemen dengan objek penelitian pengaruh Kepribadian dan Lingkungan Keluarga Terhadap Minat Berwirausaha pada Mahasiswa Jurusan Manajemen Universitas Tadulako.

Populasi dalam penelitian ini adalah seluruh mahasiswa aktif Program Studi Manajemen Fakultas Ekonomi Universitas Tadulako yaitu angkatan 2012, 2013 dan 2014.

Tabel 1 Populasi Mahasiswa Program Studi Manajemen Fakultas Ekonomi Universitas

Tadulako angkatan 2012, 2013 dan 2014

\begin{tabular}{|c|c|}
\hline Angkatan & Jumlah Mahasiswa \\
\hline 2012 & 235 \\
\hline 2013 & 214 \\
\hline 2014 & 280 \\
\hline Jumlah & $\mathbf{7 2 9}$ \\
\hline
\end{tabular}

Sumber: UPT Komputer Fakultas Ekonomi Universitas Tadulako 


\section{Yusuf M.}

Berdasarkan Tabel 1 yang menjadi populasi pada penelitian ini adalah 729 mahasiswa. Pada penelitian ini, jumlah populasi 729 orang mahasiswa jurusan manajemen dari angkatan 2012, 2013, 2014 yang dimasukkan ke dalam rumus tersebut dan menghasilkan nilai 88 (pembulatan) sampel tersebut seperti tampak sebagai berikut: $\boldsymbol{n}=\frac{729}{\mathbf{1 + 7 2 9 ( 0 . 1 ) ^ { 2 }}} \mathrm{n}=87,93$ dibulatkan menjadi 88 orang

Maka perbandingan untuk masing-masing angkatan adalah sebagai berikut:

a. Angkatan $2012: 235 / 729=0,322 \times 88$ orang $=28$ orang

b. Angkatan $2013: 214 / 729=0,294 \times 88$ orang $=26$ orang

c. Angkatan $2014: 280 / 729=0,384 \times 88$ orang $=34$ orang

Metode Analisis data dalam penelitian ini menggunakan regresi linier berganda dengan persamaani model regresi berganda sebagai berikut:

$\mathrm{Y}=\mathrm{a}+\mathrm{b} 1 \mathrm{X} 1+\mathrm{b} 2 \mathrm{X} 2+\mathrm{bnXn}+\mathrm{e}$

Dimana,

$\mathrm{Y} \quad=$ Dependen variabel

$\mathrm{X} \quad=$ Independen variabel

b1-bn $=$ Koefisien regresi

a $\quad=$ Konstanta/Intersept

e $\quad=$ Standar error

\section{Pengujian Hipotesis Pertama}

1. Jika Fhitung > Ftabel pada tingkat kepercayaan 95\% $(\alpha=0.05)$ maka terbukti variabel bebas yang diamati perpengaruh nyata (signifikan) secara simultan terhadap minat berwirausaha.

2. Jika t-hitung > t-tabel pada tingkat kepercayaan 95\% $(\alpha=0.05)$ maka terbukti variabel bebas yang diamati tidak berpengaruh nyata (signifikan) secara simultan terhadap minat berwirausaha.

\section{Pengujian Hipotesis Kedua}

1. Jika thitung $>$ ttabel pada tingkat kepercayaan 95\% $(\alpha=0.05)$ maka dapat dinyatakan bahwa secara parsial variabel bebas yang diamati berpengaruh nyata terhadap minat berwirausaha

2. Jika thitung $<$ ttabel pada tingkat kepercayaan 95\% ( $\alpha=0.05)$ maka terbukti secara parsial variabel bebas yang diamati tidak berpengaruh nyata terhadap minat berwirausaha.

\section{HASIL DAN PEMBAHASAN}

Uji Regresi Linear Berganda

Tabel 2 Hasil Perhitungan Regresi Linear Berganda

\begin{tabular}{|c|c|c|c|c|c|}
\hline \multirow[t]{2}{*}{ Variabel } & \multicolumn{2}{|c|}{$\begin{array}{l}\text { Unstandardized } \\
\text { Coefficients (B) }\end{array}$} & \multirow{2}{*}{$\begin{array}{c}\begin{array}{c}\text { Standardized } \\
\text { Coefficients }\end{array} \\
\text { Beta }\end{array}$} & \multirow[t]{2}{*}{$\mathrm{T}$} & \multirow{2}{*}{ Sig. } \\
\hline & $\mathrm{B}$ & Std. Error & & & \\
\hline (Constant $)$ & $-0,461$ & 0,687 & & $-0,671$ & 0,504 \\
\hline Kepribadian $\left(\mathrm{X}_{1}\right)$ & 0,814 & 0,171 & 0,441 & 4,764 & 0,000 \\
\hline Lingkungan Keluarga $\left(\mathrm{X}_{2}\right)$ & 0,286 & 0,093 & 0,285 & 3,076 & 0,003 \\
\hline $\mathrm{R}$ Square $\left(\mathrm{R}^{2}\right)$ & $=0,368$ & F- hitung & $=24,769$ & & \\
\hline Adjusted R Square & $=0,353$ & Constanta & $=-0,461$ & & \\
\hline Multiple R & $=0,607$ & Sig. F & $=0,000$ & & \\
\hline Jumlah data 88 Responden & & & & & \\
\hline
\end{tabular}

Sumber: Output For Windows Release 16.0, 2016 
Berdasarkan uraian Tabel 2 tentang hasil perhitungan regresi linear berganda, maka persamaan regresi yang dibangun dengan menggunakan nilai-nilai yang diperlukan sebagai berikut: $\mathrm{Y}=-0,461+$ $0,814(\mathrm{X} 1)+0,286(\mathrm{X} 2)$

Berdasarkan persamaan tersebut maka dapat dinyatakan bahwa variabel independen atau variabel bebas (Kepribadian dan Lingkungan Keluarga). Penjelasan nilai koefisien dapat diuraikan sebagai berikut:

a. Nilai konstanta (a) adalah $-0,461$, artinya apabila variabel Kepribadian (X1) dan Lingkungan Keluarga (X2) memiliki nilai 0, maka nilai variabel terikat (beta) sebesar -0,461.

b. Nilai koefisien regresi variabel Kepribadian (X1) bernilai positif yaitu 0,814. Hal ini menyatakan bahwa nilai Kepribadian meningkat maka akan meningkatkan minat berwirausaha mahasiswa Manajemen Fakultas Ekonomi Universitas Tadulako.

c. Nilai koefisien regresi variabel Lingkungan Keluarga (X2) bernilai positif yaitu 0,286. Hal ini menyatakan bahwa nilai Lingkungan Keluarga meningkat maka akan meningkatkan minat berwirausaha mahasiswa Manajemen Fakultas ekonomi Universitas Tadulako.

d. Nilai koefisien korelasi $R$ adalah 0,602. Nilai $R$ berkisar antara 0 sampai 1 , jika nilai mendekati 0 , maka hubungan antara variabel semakin lemah. Nilai yang didapat dalam penelitian ini adalah 0,602, yang artinya hubungan atau korelasi antara variabel kepribadian dan lingkungan keluarga terhadap minat berwirausaha mahasiswa manajemen Fakultas Ekonomi Universitas Tadulako kuat.

\section{Pengujian Hipotesis \\ Pengujian Hipotesis Pertama}

Berdasarkan hasil uji regresi pada tabel 3, diperoleh Fhitung sebesar 24.769 dengan tingkat signifikansi $0,000<0,05$, yang dapat diartikan bahwa variabel Kepribadian (X1) dan variabel Lingkungan Keluarga (X2) yang dimasukkan dalam model, secara serempak berpengaruh signifikan terhadap variabel Minat Berwirausaha (Y). berdasarkan hasil tersebut dapat disimpulkan bahwa H0 ditolak dan Ha diterima, atau bila dijabarkan secara mendasar bahwa dalam penelitian ini hipotesis yang pertama terbukti sebagai suatu kebenaran empiris (nyata) setelah diuji dengan hasil penelitian.

Tabel 3 Hasil Pengujian Simultan (Uji F)

\begin{tabular}{|c|c|c|c|c|c|c|}
\hline \multicolumn{6}{|c|}{ ANOVA $^{b}$} & \multirow[b]{2}{*}{ Sig. } \\
\hline & & $\begin{array}{l}\text { Sum } \\
\text { Squares }\end{array}$ & Df & Mean Square & $\mathrm{F}$ & \\
\hline \multirow[t]{3}{*}{1} & Regression & 8.696 & 2 & 4.348 & 24.769 & $.000^{\mathrm{a}}$ \\
\hline & Residual & 14.921 & 85 & .176 & & \\
\hline & Total & 23.616 & 87 & & & \\
\hline
\end{tabular}

Sumber: Output For Windows Release 16.0, 2016

\section{Pengujian Hipotesis Kedua dan Hipotesis Ketiga}

Tabel 4 Hasil Pengujian Parsial (Uji t)

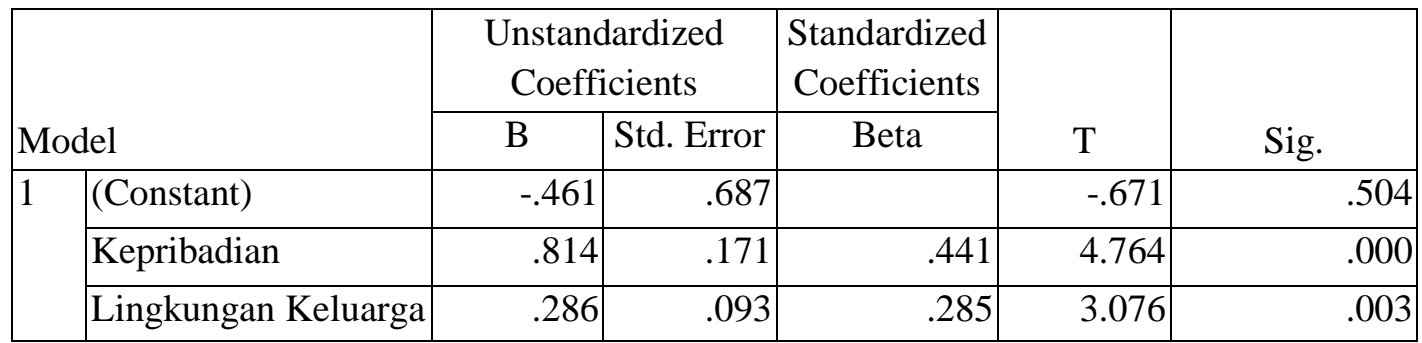

Sumber: Output For Windows Release 16.0, 2016 


\section{Yusuf M.}

Uji t dilakukan dengan membandingkan nilai t sig. dengan nilai $\alpha$. Jika probabilitas $\mathrm{t}$ sig. $<\alpha(0,05)$ maka tidak terdapat pengaruh signifikan, sebaliknya jika nilai t sig. $>\alpha(0,05)$ maka tidak terdapat pengaruh signifikan. Berdasarkan hasil pengujian yang diperoleh dalam penelitian, dapat dijelaskan hasil uji t dari variabel independen adalah sebagai berikut:

a. Kepribadian (X1)

Variabel kepribadian memiliki tingkat signifikansi $\mathrm{t}$ sig. $(0,000)<\alpha(0,05)$. Hal ini menunjukkan bahwa hipotesis yang menyatakan "Kepribadian secara parsial berpengaruh signifikan terhadap minat berwirausaha mahasiswa Manajemen Fakultas Ekonomi Universitas Tadulako" terbukti atau hipotesis tersebut diterima.

b. Lingkungan Keluarga (X2) Variabel lingkungan keluarga memiliki tinngkat signifikansi probabilitas t sig. $(0.003)<\alpha(0,05)$. Hal ini menunjukkan bahwa hipotesis yang menyatakan bahwa "Lingkungan keluarga berpengaruh signifikan terhadap minat berwirausaha mahasiswa Manajemen Fakultas Ekonomi Universitas Tadulako" terbukti atau hipotesis tersebut diterima

\section{Pembahasan Hasil Penelitian}

\section{Pengaruh Kepribadian dan Lingkungan Keluarga secara Simultan Terhadap Minat Berwirausaha Mahasiswa Manajemen Fakultas Ekonomi Universitas Tadulako}

Variabel Kepribadian dan Lingkungan Keluarga pada mahasiswa Manajemen Fakultas Ekonomi Universitas Tadulako memiliki peranan yang signifikan terhadap minat berwirausaha. Hal ini dapat dilihat bahwa Kepribadian dan Lingkungan Keluarga pada mahasiswa Manajemen Fakultas ekonomi Universitas Tadulako merupakan variabel yang mempengaruhi minat berwirausaha disamping variabel lainnya yang tidak dibahas dalam penelitian ini. Sumbangan pengaruh Kepribadian dan Lingkungan Keluarga terhadap minat berwirausaha mahasiswa sebesar 36,8\%. Hal ini berarti masih ada 63,2\% faktor-faktor lainnya yang mempengaruhi minat berwirausaha mahasiswa Manajemen Fakultas Ekonomi Universitas Tadulako yang masuk dalam model pada penelitian ini. Berdasarkan Tabel 5.15 diketahui besarnya Fhitung 24,769 pada signifikan probabilitas 0,000, menunjukkan bahwa terdapat pengaruh yang positif dan signifikan dari variabel Kepribadian dan Lingkungan Keluarga terhadap minat berwirausaha mahasiswa Manajemen Fakultas Ekonomi Universitas Tadulako.

\section{Pengaruh Kepribadian secara Parsial Terhadap Minat Berwirausaha Mahasiswa Manajemen Fakultas Ekonomi Universitas Tadulako}

Berdasarkan hasil pengujian koefisien untuk variabel kepribadian adalah sebesar 0,814 , hal ini berarti ketika kepribadian ditingkatkan maka minat berwirausaha mahasiswa akan meningkat sebesar $81,4 \%$. Sedangkan uji t menunjukkan bahwa thitung yang diperoleh sebesar 4,764 pada tingkat signifikansi 0,000 , sehingga dapat disimpulkan bahwa variabel kepribadian berpengaruh signifikan terhadap minat berwirausaha mahasiswa Manajemen Fakultas Ekonomi Universitas Tadulako. Hal ini juga menunjukkan bahwa hipotesis kedua diterima "Kepribadian berpengaruh signifikan terhadap minat berwirausaha mahasiswa Manajemen Fakultas Ekonomi Universitas Tadulako" terbukti.

Hasil penelitian ini sejalan dengan penelitian yang dilakukan oleh Aflit Nuryulia Praswati (2014) yang menyatakan bahwa kepribadian terbukti berpengaruh positif terhadap minat berwirausaha mahasiswa (studi kasus Fakultas Ekonomi dan bisnis Universitas Muhammadiyah Surakarta) Penelitian ini juga sejalan dengan penelitian yang dilakukan oleh Eka Aprilianty hasil penelitian menunjukkan bahwa keperibadian, pengetahuan kewirausahan, lingkungan keluarga memiliki pengaruh yang signifikan terhadap minat berwirausaha siswa SMK Negeri 1 Nanggulan Kulon Progo, SMK negeri pandak bantul, SMK indonesia YIPK bantul, dan SMK perkebunan MM 52 kota Yogyakarta. 


\section{Pengaruh Lingkungan keluarga secara Parsial Terhadap Minat Berwirausaha Mahasiswa Manajemen Fakultas Ekonomi Universitas Tadulako}

Berdasarkan hasil penelitian koefisien untuk variabel Lingkungan keluarga adalah sebesar 0,286 atau 28,6\%. Hal ini berarti jika lingkungan keluarga ditingkatkan, maka minat berwirausaha mahasiswa Manajemen Fakultas Ekonomi Universitas Tadulako akan meningkat sebesar 28,6 \%. Sedangkan uji t menunjukkan bahwa thitung yang diperoleh sebesar 3,076 pada tingkat signifikansi 0,001, sehingga dapat disimpulkan bahwa variable Lingkungan keluarga berpengaruh signifikan terhadap minat berwirausaha mahasiswa Manajemen Fakultas Ekonomi Universitas Tadulako. Hal ini juga menunjukkan bahwa hipotesis kedua diterima yakni "Lingkungan keluarga berpengaruh signifikan terhadap minat berwirausaha mahasiswa Manajemen Fakultas Ekonomi Universitas Tadulako" terbukti.

Hasil penelitian ini sejalan dengan penelitian yang dilakukan Ridwan Lutfiadi dan M. Ikhwan Rahmanto (2011) yang menyatakan bahwa pendidikan kewirausahawan, kepribadian dan lingkungan berpengaruh signifikan terhadap minat berwirausaha SMK di kota Bekasi. Penelitian ini juga sejalan dengan penelitian yang dilakukan Yudi Siswadi (2013) Dari hasil penelitian yang telah dilakukan bahwa faktor internal (motivasi, prestasi dan kepribadian), faktor eksternal (keluarga dan lingkungan sosial) dan pembalajaran memiliki pengaruh yang signifikan terhadap minat berwirausaha

\section{KESIMPULAN DAN SARAN}

\section{Kesimpulan}

Berdasarkan uraian hasil penelitian dan pembahasan, maka dapat disimpulkan sebagai berikut:

1. Kepribadian dan lingkungan keluarga secara bersama-sama berpengaruh positif dan signifikan secara simultan terhadap minat berwirausaha mahasiswa Manajemen Fakultas Ekonomi Universitas Tadulako.

2. kepribadian berpengaruh positif dan signifikan secara parsial terhadap minat berwirausaha mahasiswa Manajemen Fakultas Ekonomi Universitas Tadulako.

3. Lingkungan keluarga berpengaruh positif dan signifikan secara parsial terhadap minat berwirausaha mahasiswa Manajemen Fakultas Ekonomi Universitas Tadulako.

\section{Saran}

Berdasarkan hasil kesimpulan dari analisa yang dilakukan, maka penulis memberikan beberapa hal yang dapat diperhatikan dalam rangka meningkatkan minat berwirausaha mahasiswa Manajemen Fakultas Ekonomi Universitas Tadulako yaitu:

1. Hasil penelitian ini yaitu minat berwirausaha mahasiswa jurusan Manajeman Universitas Tadulako hanya bisa dijelaskan sebesar 36,8\% oleh kedua variabel bebas yaitu kepribadian dan lingkungan keluarga, hal ini berarti ada $63,2 \%$ faktor-faktor lainnya yang mempengaruhi minat berwirausaha mahasiswa jurusan Manajemen Fakultas Ekonomi Universitas Tadulako yang tidak masuk dalam penelitian ini Untuk penelitian yang akan datang sebaiknya dapat menambah variabel lain selain kedua variabel tersebut.

2. Variabel kepribadian, dari enam dimensi kepribadian (percaya diri, berorintasi pada tugas, pengambilan resiko, kepemimpinan, keorisinilan dan berorientasi ke masa depan) dimensi percaya diri dan keorisinilan memperoleh nilai maen sebesar 4,31 dan yang tertinggi dari 6 dimensi lainnya diharapkan mahasiswa hendaknya dapat mempertahankan hal tersebut. Selanjutnya, dimensi kepemimpinan memiliki nilai mean terendah yakni 3.98. salah satu alasan suatu organisasi dapat berjalan dengan didukung kepemimpinan yang baik. Diharapkan kepada mahasiswa universitas tadulako dapat meningkatkan nilai kepemimpinannya guna mendukung keberlangsungngan usaha yang akan dimilkinya nanti terutama dalam hal berwirausaha. 


\section{Yusuf M.}

3. Variabel lingkungan keluarga, dari tiga dimensi lingkungan keluarga (keberfungsian keluarga, sikap dan perlakuan orang tua dan status ekononi. Dimensi keberfungsian kerluarga memperoleh nilai mean 4.35 dan yang tertinggi dari dua dimensi lainnya. Ini menunjukan keluarga sudah menjalankan fungsinya dengan baik. Selanjutnya dimensi sikap dan perlakuan orang tua memperoleh nilai mean terendah yakni 3.98, diharapkan Keluarga diharapkan lebih aktif dan mampu memberikan dukungannya terhadap aktivitas berwirausaha yang dijalankan oleh anak, sehingga dengan kontribusi yang lebih aktif dari keluarga dapat mendorong dan memberikan pengaruh positif bagi proses usaha yang dijalankannya, baik kontribusi dari segi pendanaan maupun non pendanaan.

4. Penelitian selanjutnya diharapkan dapat memperluas variabel penelitian di luar variabel independen yang terdapat dalam penelitian ini dan diharapkan pada penelitian selanjutnya dapat menggunakan sampel yang lebih besar, sehingga akan didapatkan faktor-faktor apa saja yang mempengaruhi aktivitas berwirausaha mahasiswa secara lebih luas.

5. Kesimpulan terakhir adalah, mahasiswa setelah lulus nanti tidak hanya berorientasi untuk mencari kerja, namun juga berusaha untuk menciptakan lapangan pekerjaan agar bisa membatu dalam hal mengurangi pengangguran.

\section{REFERENSI}

Alma, Buchari. 2011. Kewirausahaan. Bandung: Alfabeta

Aprilianty, Eka. 2012. Pengaruh Keperibadian Wirausaha, Pengetahuan Kewirausahaan, dan Lingkungan Terhadap Minat Berwirausaha Siswa SMK. SMK Muhammadiyah Pangkalan Bun, Kal-Teng. Jurnal Pendidikan Vokasi. Vol. 2 No.3. Hal. 311-324.

Daryanto dan Aris Dwi Cahyono. 2013. Kewirausahaan. Yogyakarta : Gava Media.

Ghozali,Imam (2006), Aplikasi Analisis Multivariate Dengan Program IBM Spss 19 (Edisi Kelima), Semarang. Universitas Diponegoro

Hambali, Adang dan Ujam Jaenudin. 2013. Psikologi Kepribadian. Bandung: Pustaka Setia

Lutfiadi, Ridwan dan M. Ikhwan Rahmanto. 2011. Analisis Peran Pendidikan Kewirausahaan, Keperibadian, dan Lingkungan Terhadap Minat Siswa SMK Untuk Berwirausaha. Bekasi. Jurnal Agribisnis dan Pengembangan Wilayah Vol. 3 No. 1. Hal 56-65.

Paulina, Irene dan Wardoyo. 2012. Pengaruh Kecerdasan Emosi, Sikap Mandiri, dan Lingkungan Terhadap Intensi Berwirausaha Pada Mahasiswa Jurnal Dinamika Manajemen,Vol.3,No.1,Maret 2012

Praswati, Aflit Nuryulia. 2014. Analisis Faktor-Faktor Yang Mempengaruhi Minat Wirausaha dikalangan Mahasiswa. Universitas Muhammadiyah Surakarta. Seminar Nasional dan CALL Paper: Research Methods and Organizational Studies.. ISBN: 978-602-70429-1-9. Hal 134-142.

Siswadi, Yudi. 2013. Analisis Faktor Internal, Faktor Eksternal dan Pembelajaran Kewirausahawan yang Mempengaruhi Minat Berwirausaha Mahasiswa dalam Berwirausaha. Jurnal Manajemen dan Bisnis Vol 13 No.1 April 2013 ISSN 16937619.

Sugiyono, 2010. Statistika Untuk Penelitian. Bandung: Alfabeta.

Totok S, Wiryasaputra. 2004. Entrepreneur: Anda Merdeka jadi bos. Jakarta: Tridaharma Manunggal. Yusuf, Syamsu. 2008. Teori Kepribadian. Bandung: PT.Remaja Rosdakarya. 